\title{
Deoxyribonucleic Acid Relatedness among Species of the Genus Saccharomyces Sensu Stricto
}

\author{
ANN VAUGHAN MARTINI ${ }^{1 *}$ AND CLETUS P. KURTZMAN ${ }^{2}$ \\ Instituto di Biologia Vegetale, Sezione di Microbiologia, Università degli Studi, 06100 Perugia, Italy, ${ }^{1}$ and Northern \\ Regional Research Center, Agricultural Research Service, U.S. Department of Agriculture, Peoria, Illinois $61604^{2}$
}

\begin{abstract}
Twenty-four species assigned to the genus Saccharomyces sensu stricto were examined for deoxyribonucleic acid relatedness. Results with type strains demonstrated the presence of four distinct species: $S$. cerevisiae, $S$. bayanus, $S$. carlsbergensis, and $S$. kluyveri. $S$. carlsbergensis NRRL Y-12693 ${ }^{\mathrm{T}}$ showed intermediate relatedness between $S$. cerevisiae and $S$. bayanus and has a genome size approximately 1.5 times those of the last two species. These data suggest $S$. carlsbergensis to be a partial amphidiploid which may have arisen from natural hybridization between $S$. cerevisiae and $S$. bayanus.
\end{abstract}

Numerous studies in recent years have shown that the criteria used in traditional yeast taxonomy are not always satisfactory for delimitation of species. This is partly because many separations are based on the presence or absence of assimilative abilities which are often controlled by a single mutable gene $(12,14,18,23,25)$. The species of Saccharomyces sensu stricto (34) provide a good example of this problem because of strain variability in standard carbon assimilation and fermentation tests $(5,16,28,34,35,36)$. As a result of the uncertainty of these tests, a number of other approaches have been attempted, such as comparisons of cell wall antigens $(2,10,11,27)$, proton magnetic resonance spectra of extracted mannans $(11,32)$, and attempted matings between haploid mating types of similar species (3, 21). Requirements for vitamins (9) and amino compounds (7) have also been used for taxonomic separations, as have differences in deoxyribonucleic acid (DNA) base composition (guanine plus cytosine $[\mathrm{G}+\mathrm{C}]$ contents in moles percent) (36). Finally, numerical analyses $(1,8,15,17)$ by Adansonian principles have been used for species separations. None of these methods, however, seems to have resolved the status of the species investigated (25).

More significant information concerning taxonomic relationships among yeasts is obtainable by comparison of their nucleic acids $(18,25)$. In this light, some progress has been made with regard to Saccharomyces spp. Bicknell and Douglas (6) determined DNA relatedness among several species, whereas Rosini et al. (26) concluded from their DNA studies that common wine yeasts comprised at least three Saccharomyces species. In the present study, we measured DNA relatedness among all taxa assigned to Saccharomyces sensu stricto $(34,35,36)$ in an effort to clarify their relationships.

\section{MATERIALS AND METHODS}

Microorganisms. Twenty-nine strains representing 24 species were examined. Strain designations are given in Table 1.

DNA purification, determination of $\mathbf{G}+\mathrm{C}$ contents, and reannealing reactions. Extraction and purification of DNA was accomplished by a combination of the procedures of Marmur (20) and Bernardi et al. (4), as described by Price et al. (25). Ratios of absorbance at 260:280 and 230:260 nm

\footnotetext{
* Corresponding author.
}

were used to assess DNA purity, as were thermal melting profiles and ultracentrifuge scans.

The $\mathrm{G}+\mathrm{C}$ contents of nuclear DNAs were calculated from buoyant density values in cesium chloride $(29,33)$ based on three or four separate determinations made with a model $\mathrm{E}$ analytical ultracentrifuge (Beckman Instruments, Inc.) equipped with an electronic scanner. Micrococcus luteus (synonym, M. lysodeikticus) DNA was used as a reference; this DNA has a buoyant density of $1.7311 \mathrm{~g} / \mathrm{ml}$ (25).

The extent of DNA reassociation was determined spectrophotometrically by using essentially the method reported by Seidler and Mandel (31) and Seidler et al. (30), as described by Kurtzman et al. (19).

Genome size. Estimates of genome size were determined by comparisons of $\mathrm{C}_{0} \mathrm{t}_{0.5}$ values $\left(\mathrm{C}_{0} \mathrm{t}=\right.$ initial nucleotide concentration in moles per liter $\times$ time in seconds) obtained from reassociation kinetics (31). The relative genome size of $S$. cerevisiae was defined as 1.00 for this comparison.

Single-cell isolates. Single vegetative cell isolates, used in certain comparisons, were obtained by micromanipulation.

\section{RESULTS}

Origins of the strains and $\mathrm{G}+\mathrm{C}$ contents of the nuclear DNAs are listed in Table 1 . Neither habitat nor DNA base composition provided evidence of taxonomic value. Consequently, more significant comparisons were sought from DNA reassociation studies.

Results obtained from DNA hybridization studies (Tables 2 and 3 ) suggest that the 24 taxa compared comprise four species. Of these taxa, 15 showed high relatedness with $S$. cerevisiae (Table 2), and 5 showed high relatedness with $S$. bayanus (Table 3). Little relatedness was detected between $S$. kluyveri and the other species included in this study.

Of particular interest were reassociations involving $S$. carlsbergensis. This species and S. cerevisiae showed $57 \%$ relatedness, whereas the extent of its complementarity with $S$. bayanus was $72 \%$. To preclude the possibility that mixedstock cultures were not responsible for these results, we made single-cell isolates from the type strains of all three species. Reassociations involving DNA from single-cell isolates gave the same results. Relative genome sizes were estimated from reassociation kinetics (31) and found to vary among the type strains of the three species: $S$. cerevisiae, $1.00 ;$ S. bayanus, 1.22 ; and $S$. carlsbergensis, 1.49 . 
TABLE 1. Species of Saccharomyces sensu stricto examined

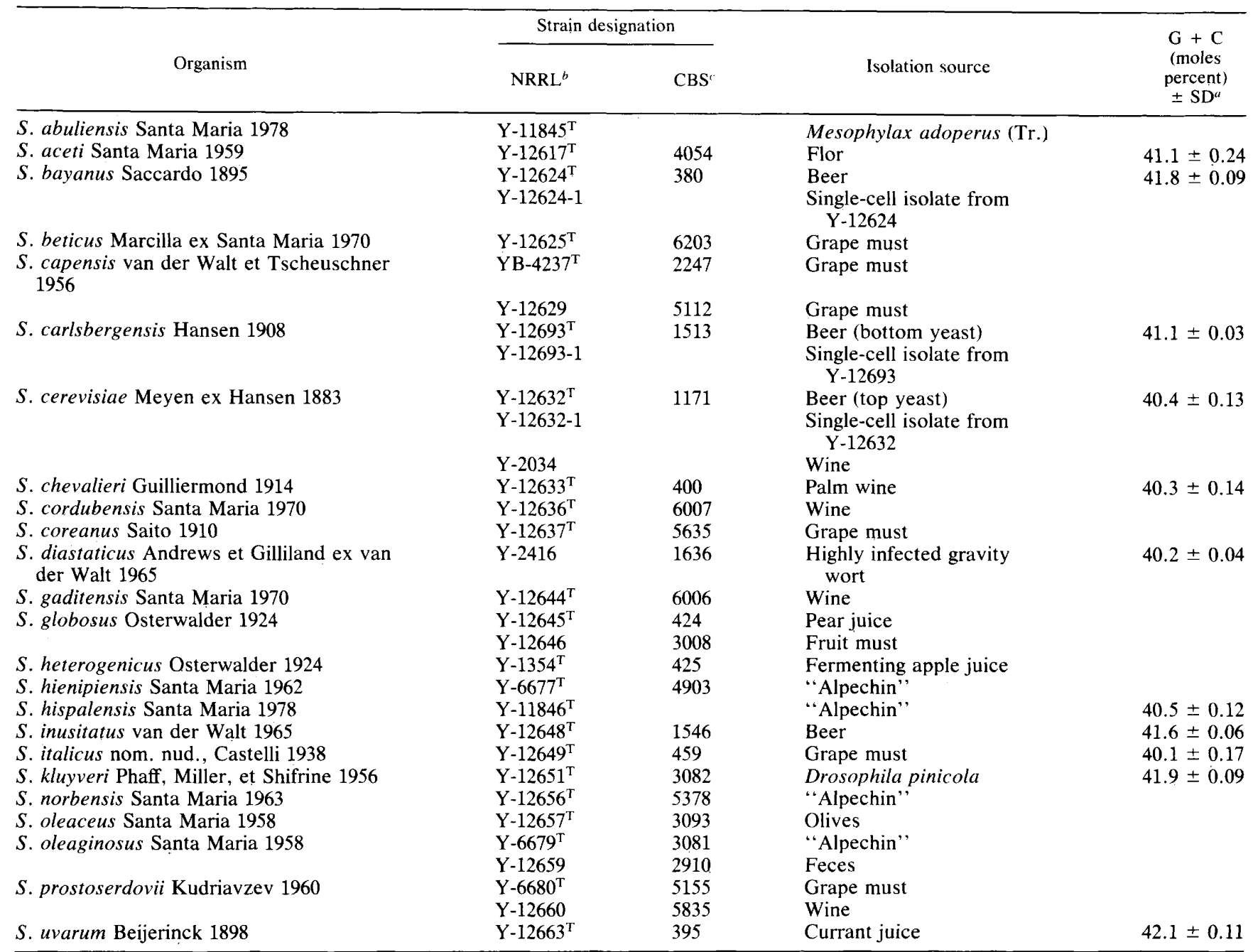

${ }^{a}$ Mean \pm standard deviation. Standard deviations were calculated from three determinations.

${ }^{b}$ NRRL, Northern Regional Research Center, Peoria, Ill.

c CBS, Centraalbureau voor Schimmelcultures, Baarn, The Netherlands.

\section{DISCUSSION}

The controversies that have surrounded definition of species in Saccharomyces sensu stricto were caused, for the most part, by heavy reliance on fermentation and assimilation of carbon compounds, particularly sugars, as primary taxonomic criteria. This philosophy led to the description of many taxa that we have now shown to be synonyms of $S$. cerevisiae or $S$. bayanus. Although some conspecificity within Saccharomyces sensu stricto has been recognized in recent years after reevaluation of data from standard morphological and physiological tests $(5,35,36)$, these tests appear incapable of discriminating all species. For example, $S$. carlsbergensis has been considered a synonym of $S$. uvarum (34) as well as of $S$. cerevisiae (35).

Confirmation of $S$. kluyveri as a distinct species was expected for a number of reasons. Its ecological isolation (in tree exudates) from the other species placed in Saccharomyces sensu stricto, as well as its inability to form "petite colonies" prompted van der Walt (34) to place it in his Saccharomyces group II. Meyer and Phaff (22) and Yarrow and Nakase (36) transferred it to group I; they considered it closely allied although distinct from $S$. cerevisiae. Lastly, Barker and Miller (3) obtained only infertile hybrids in mating studies between $S$. kluyveri and $S$. cerevisiae despite physiological cross-reactions of their mating pheromones observed later by McCullough and Herskowitz (21).

Although our data clearly show $S$. cerevisiae and $S$. bayanus to be separate taxa, it is not evident why populations so similar in morphology, physiology, and habitat would have evolved into separate species. Further studies are needed to examine this interesting example of sympatry.

It was unexpected to find that $S$. carlsbergensis $\mathrm{Y}-12693^{\mathrm{T}}$ showed relatively high DNA relatedness to both $S$. cerevisiae and $S$. bayanus. These observations can be explained by the proportionally larger genome size of this strain of $S$. carlsbergensis. We suggest that $S$. carlsbergensis $\mathrm{Y}-12693^{\mathrm{T}}$ may represent a natural hybrid between these two species. This hybrid is probably a partial amphidiploid because its genome size is not quite double that of the proposed parents. Furthermore, the $S$. bayanus parent of this hybrid was probably a strain formerly classified as $S$. uvarum because both $S$. carlsbergensis and $S$. uvarum ferment melibiose, whereas strains originally classified as $S$. bayanus did not 
TABLE 2. Extent of DNA reassociation between $S$. cerevisiae NRRL Y $-12632^{\mathrm{T}}$ and other species of Saccharomyces sensu stricto

\begin{tabular}{llc}
\hline \multicolumn{1}{c}{ Species } & $\begin{array}{c}\mathrm{NRRL}^{a} \\
\text { no. }\end{array}$ & $\begin{array}{c}\text { \% DNA } \\
\text { reassociation }\end{array}$ \\
\hline Saccharomyces aceti & $\mathrm{Y}-12617^{\mathrm{T}}$ & 96 \\
S. beticus & $\mathrm{Y}-12625^{\mathrm{T}}$ & 99 \\
S. capensis & $\mathrm{YB}-4237^{\mathrm{T}}$ & 94 \\
& $\mathrm{Y}-12629$ & 99 \\
S. cerevisiae & $\mathrm{Y}-2034$ & 91 \\
S. chevalieri & $\mathrm{Y}-12633^{\mathrm{T}}$ & 96 \\
S. cordubensis & $\mathrm{Y}-12636^{\mathrm{T}}$ & 100 \\
S. coreanus & $\mathrm{Y}-12637^{\mathrm{T}}$ & 94 \\
S. diastaticus & $\mathrm{Y}-2416$ & 92 \\
S. gaditensis & $\mathrm{Y}-12644^{\mathrm{T}}$ & 95 \\
S. hienipiensis & $\mathrm{Y}-6677^{\mathrm{T}}$ & 95 \\
S. hispalensis & $\mathrm{Y}-11846^{\mathrm{T}}$ & 94 \\
S. italicus & $\mathrm{Y}-12649^{\mathrm{T}}$ & 96 \\
S. norbensis & $\mathrm{Y}-12656^{\mathrm{T}}$ & 90 \\
S. oleaceus & $\mathrm{Y}-12657^{\mathrm{T}}$ & 94 \\
S. oleaginosus & $\mathrm{Y}-6679^{\mathrm{T}}$ & 89 \\
& $\mathrm{Y}-12659$ & 86 \\
S. prostoserdovii & $\mathrm{Y}-6680^{\mathrm{T}}$ & 93 \\
S. carlsbergensis & $\mathrm{Y}-12660$ & 101 \\
S. abuliensis & $\mathrm{Y}-12693^{\mathrm{T}}$ & 57 \\
S. bayanus & $\mathrm{Y}-11845^{\mathrm{T}}$ & 15 \\
S. globosus & $\mathrm{Y}-12624^{\mathrm{T}}$ & 5 \\
S. heterogenicus & $\mathrm{Y}-12645^{\mathrm{T}}$ & 3 \\
S. inusitatus & $\mathrm{Y}-12646$ & 8 \\
S. kluyveri & $\mathrm{Y}-1354^{\mathrm{T}}$ & 20 \\
S. uvarum & $\mathrm{Y}-12648^{\mathrm{T}}$ & 24 \\
Debaryomyces melissophilus & $\mathrm{Y}-12651^{\mathrm{T}}$ & -3 \\
\hline . NRRL, & $\mathrm{Y}-12663^{\mathrm{T}}$ & 14 \\
& $\mathrm{Y}-7585^{\mathrm{T}}$ & 6 \\
\hline & &
\end{tabular}

${ }^{a}$ NRRL, Northern Regional Research Laboratory, Peoria, Ill.

${ }^{b}$ Mean value of two to four determinations. Standard deviation, $\leq 5 \%$.

ferment this sugar. Bicknell and Douglas (6) reported $96 \%$ DNA homology between $S$. cerevisiae and $S$. carlsbergensis and $40 \%$ homology between $S$. cerevisiae and $S$. uvarum $(S$. bayanus). The reason for the difference between their results and ours is unknown. We can only comment that their cultures were not the type strains of these species. In support of the idea that $S$. cerevisiae and $S$. carlsbergensis are separate taxa, Holmberg (13) noted that these two species had distinct differences in various zones of chromosome III. Additionally, Nilsson-Tillgren et al. (24) have demonstrated the possibility of single-chromosome transfers between $S$. cerevisiae and $S$. carlsbergensis. In the absence of contrary genetic evidence, we might expect that $S$.

TABLE 3. Extent of DNA reassociation between $S$. bayanus NRRL Y $-12624^{\mathrm{T}}$ and Saccharomyces sensu stricto species showing low DNA relatedness with $S$. cerevisiae

\begin{tabular}{llc}
\hline \multicolumn{1}{c}{ Species } & $\begin{array}{c}\mathrm{NRRL}^{a} \\
\text { no. }\end{array}$ & $\begin{array}{c}\% \text { DNA } \\
\text { reassociation }^{b}\end{array}$ \\
\hline Saccharomyces abuliensis & $\mathrm{Y}-11845^{\mathrm{T}}$ & 91 \\
S. globosus & $\mathrm{Y}-12645^{\mathrm{T}}$ & 104 \\
& $\mathrm{Y}-12646$ & 87 \\
S. heterogenicus & $\mathrm{Y}-1354^{\mathrm{T}}$ & 86 \\
S. inusitatus & $\mathrm{Y}-12648^{\mathrm{T}}$ & 94 \\
S. uvarum & $\mathrm{Y}-12663^{\mathrm{T}}$ & 98 \\
S. carlsbergensis & $\mathrm{Y}-12693^{\mathrm{T}}$ & 72 \\
S. kluyveri & $\mathrm{Y}-12651^{\mathrm{T}}$ & 24 \\
Debaryomyces melissophilus & $\mathrm{Y}-7585^{\mathrm{T}}$ & 1 \\
\hline
\end{tabular}

a NRRL, National Regional Research Laboratory, Peoria, Ill.

${ }^{b}$ Mean value of two to four determinations. Standard deviation, $\leq 5 \%$. carlsbergensis would not form fully fertile hybrids with either $S$. cerevisiae or $S$. bayanus. If this prediction proves true, $S$. carlsbergensis will have to be considered a species distinct from its parents.

\section{ACKNOWLEDGMENTS}

Our thanks to Millie Jo Smiley, Christie J. Robnett, and Massimo Bellini for valuable technical assistance.

\section{LITERATURE CITED}

1. Banno, I. 1975. Saccharomyces yeasts isolated in Japan: (1) A numerical analysis of $S$. cerevisiae and its allied species. IFO Res. Comm. 7:15-23.

2. Ballou, C. E., P. N. Lipke, and W. C. Raschke. 1974. Structure and immunochemistry of the cell wall mannans from Saccharomyces chevalieri, Saccharomyces italicus, Saccharomyces diastaticus, and Saccharomyces carlsbergensis. J. Bacteriol. 117:461-467.

3. Barker, E. R., and M. W. Miller. 1969. Some properties of Saccharomyces kluyveri. Antonie van Leeuwenhoek J. Microbiol. Serol. 35:159-171.

4. Bernardi, G. M., M. Foures, J. Piperno, and P. P. Slonimski. 1970. Mitochondrial DNA from respiratory-sufficient and cytoplasmic respiratory-deficient mutants of yeast. J. Mol. Biol. 18:23-43.

5. Barnett, J. A., R. W. Payne, and D. Yarrow. 1983. Yeasts: characteristics and identification, p. 467-474. Cambridge University Press, Cambridge.

6. Bicknell, J. N., and H. C. Douglas. 1970. Nucleic acid homologies among species of Saccharomyces. J. Bacteriol. 101: 505-512.

7. Brady, B. 1965 . Utilization of amino compounds by yeasts of the genus Saccharomyces. Antonie van Leeuwenhoek J. Microbiol. Serol. 31:95-102.

8. Campbell, J. 1973. Computer identification of yeasts of the genus Saccharomyces. J. Gen. Microbiol. 77:127-135.

9. Fiol, J. B. 1976. Systématique des Saccharomyces: osidases et besoins vitaminiques. Mycopathologia 58:19-58.

10. Fukazawa, Y., T. Shinoda, A. Nishikawa, and T. Nakase. 1980. Synonymy of Saccharomyces cerevisiae Hansen 1883 and Saccharomyces uvarum Beijerinck 1898: significance of cell wall antigens in yeast classification. Int. J. Syst. Bacteriol. 30:196-205.

11. Fukazawa, Y., A. Nishikawa, M. Suzuki, and T. Shinoda. 1980. Immunological basis of the serological specificity of the yeasts: Immunochemical determinants of several antigenic factors in yeasts, p. 127-136. In H. Preusser (ed.), Medical mycology. Gustav Fischer Verlag, New York.

12. Hansen, E. C. 1908 . Recherches sur la physiologie et la morphologie des ferments alcooliques. XIII. Nouvelles études sur des levures de brasserie á fermentation basse. C. R. Trav. Lab, Carlsberg 7:179-217.

13. Holmberg, S. 1982. Genetic differences between Saccharomyces carlsbergensis and $S$, cerevisiae. II. Restriction endonuclease analysis of genes in chromosome III. Carlsberg Res. Commun. 47:233-244.

14. Johnson, J. L. 1981. Genetic characterization, p. 450-472. In P. Gerhardt (ed.), Manual of methods for general bacteriology. American Society for Microbiology, Washington, D.C.

15. Jones, C. R. 1975. A comparison of analytical methods for the numerical taxonomy of yeasts. J. Gen. Microbiol. 89:175-181.

16. Kocková-Kratochvílová, A. 1976. Taxometric study of the genus Saccharomyces (Meyen/Reess) 3rd part: small species. Biologické Pràce. Veda, Vydavatelstvo Slovenskej Akadémie Vied, Bratislava, Yugloslavia.

17. Kocková-Kratochvílová, A., M. Pokorná, and J. Sandula. 1966. The genus Saccharomyces (Meyen) Reess: I. A group of fermentation type II species completely fermenting raffinose. Folia Microbiol. 11:188-199.

18. Kurtzman, C. P., H. J. Phaff, and S. A. Meyer. 1983. Nucleic acid relatedness among yeasts, p. 139-166. In J. F. T. Spencer, D. M. Spencer, and A. R. W. Smith (ed.), Yeast 
genetics-fundamental and applied aspects. Springer-Verlag, New York.

19. Kurtzman, C. P., M. J. Smiley, C. J. Johnson, L. J. Wickerham, and G. B. Fuson. 1980. Two new and closely related heterothallic species, Pichia amylophila and Pichia mississippiensis: characterization by hybridization and deoxyribonucleic acid reassociation. Int. J. Syst. Bacteriol. 30:208-216.

20. Marmur, J. 1961. A procedure for the isolation of DNA from microorganisms. J. Mol. Biol. 3:208-218.

21. McCullough, J., and I. Herskowitz. 1979. Mating pheromones of Saccharomyces kluyveri: pheromone interactions between Saccharomyces kluyveri and Saccharomyces cerevisiae. J. Bacteriol. 138:146-154.

22. Meyer, S. A., and H. J. Phaff. 1969. Deoxyribonucleic acid base composition in yeasts. J. Bacteriol. 97:52-56.

23. Naumov, G. I. 1969. Comparative genetics of yeasts. I. Complementation of the genes for maltose utilization in maltosenegative species of Saccharomyces. Genetika 5:142-149.

24. Nilsson-Tillgren, T. J., G. L. Peterson, S. Holmberg, and M. C. Kielland-Brandt. 1980. Transfer of chromosome III during kar mediated cytoduction in yeast. Carlsberg Res. Commun. 45:113-117.

25. Price, C. W., G. B. Fuson, and H. J. Phaff. 1978. Genome comparison in yeast systematics: delimitation of species within the genera Schwanniomyces, Saccharomyces, Debaryomyces, and Pichia. Microbiol. Rev. 42:161-193.

26. Rosini, G. F., F. Federici, A. E. Vaughan, and A. Martini. 1982. Systematics of the species of the yeast genus Saccharomyces associated with the fermentation industry. Eur. J. Appl. Microbiol. Biotechnol. 15:188-193.

27. Sandula, J., and A. Kocková-Kratochvílová. 1966. Serological study of the species Saccharomyces monacensis Hansen.
Biològia (Bratislava) 21:252-261.

28. Santa Maria, J. 1978. Biotaxonomic studies on yeast, p. 1-59. Commun. I.N.I.A., Madrid.

29. Schildkraut, C. L., J. Marmur, and P. Doty. 1962. Determination of the base composition of deoxyribonucleic acid from its buoyant density in CsCl. J. Mol. Biol. 4:430-433.

30. Seidler, R. J., M. D. Knittel, and C. Brown. 1975. Potential pathogens in the environment: cultural reactions and nucleic acid studies on Klebsiella pneumoniae from clinical and environmental sources. Appl. Microbiol. 29:819-825.

31. Seidler, R. J., and M. Mandel. 1971. Quantitative aspects of deoxyribonucleic acid renaturation: base composition, state of chromosome replication, and polynucleotide homologies. J. Bacteriol. 106:608-614.

32. Spencer, J. F. T., and P. A. J. Gorin. 1969. Systematics of the genera Saccharomyces, Schizosaccharomyces, Endomycopsis, Kluyveromyces, Schwanniomyces and Brettanomyces: proton magnetic resonance spectra of the mannans and mannosecontaining polysaccharides as an aid in classification. Antonie van Leeuwenhoek J. Microbiol. Serol. 35:361-378.

33. Szybalski, W. 1968. Use of cesium sulfate for equilibrium density gradient centrifugation. Methods Enzymol. 12B: $330-360$.

34. van der Walt, J. P. 1970. Saccharomyces Meyen emend. Reess, p. 555-718. In J. Lodder (ed.), The yeasts: a taxonomic study. Elsevier/North-Holland Publishing Co., Amsterdam.

35. Yarrow, D. 1984. Saccharomyces Meyen ex Reess, p. 379-395. In N. J. W. Kreger-van Rij (ed.), The yeasts: a taxonomic study. Elsevier Science Publishing, Inc., New York.

36. Yarrow, D., and T. Nakase. 1975. DNA base composition of species of the genus Saccharomyces. Antonie van Leeuwenhoek J. Microbiol. Serol. 41:81-88. 